\title{
Physiological parameters in sugarcane cultivars submitted to water deficit
}

\section{José Perez da Graça ${ }^{1,2}$, Fabiana Aparecida Rodrigues², José Renato Bouças Farias², Maria Cristina Neves de Oliveira ${ }^{2}$, Clara Beatriz Hoffmann-Campo ${ }^{2 *}$ and Sonia Marli Zingaretti ${ }^{3}$}

\author{
${ }^{1}$ Universidade Estadual Paulista "Júlio de Mesquita Filho", Via de Acesso Prof. Paulo Donato Castellane, s/n, \\ 14884-900, Jaboticabal, SP, Brasil. \\ 2 Embrapa Soja, Caixa Postal 231, 86001-970 Londrina, PR, Brasil. \\ ${ }^{3}$ Universidade de Ribeirão Preto, Avenida Costábile Romano, 2201, 14096-900, Ribeirão Preto, SP, Brasil.
}

*Corresponding author: hoffmann@cnpso.embrapa.br. Tel. +55 43 3371 6214; fax: +55 4333716100.

Received: 21 June 2010; Accepted: 29 October 2010

\begin{abstract}
To investigate the processes involved in the susceptibility of sugarcane plants to water deficit, several physiological parameters were evaluated in drought tolerant (SP83-2847 and CTC15) and sensitive (SP86-155) cultivars. The water deficit affected the photosynthetic apparatus of all the plants in different ways, within and among cultivars. The photosynthetic rate and stomatal conductance decreased significantly in all cultivars submitted to water deficit. In control plants of the tolerant cultivars (SP83-2847 and CTC15) the photosynthetic rate was higher than in the sensitive cultivar (SP86-155). Cultivar CTC15 showed the highest relative water content during the dry period. The quantum efficiency photosystem II of cultivar SP83-2847 was more stable in the last days of the experimental treatment, suggesting that the decline in relative water content stimulated an adjustment of photosynthetic capacity to tolerate the changes in water availability. As a whole, the tolerant SP83-2847 and CTC15 cultivars exhibited a better photosynthetic performance than the sensitive SP86-155 cultivar. The data suggest that these physiological parameters can be used in the evaluation and distinction of drought tolerant and sensitive sugarcane genotypes.
\end{abstract}

Key words: Photosynthetic efficiency, relative water content, Saccharum, water stress, drought.

\section{RESUMO}

Parâmetros fisiológicos de cultivares de cana-de-açúcar submetidas ao déficit hídrico. Para investigar o processo envolvido na susceptibilidade de plantas de cana-de-açúcar ao déficit hídrico, diferentes parâmetros fisiológicos foram avaliados em cultivares tolerantes (SP83-2847 e CTC15) e sensível (SP86-155) ao déficit hídrico. 0 déficit hídrico afetou 0 aparato fotossintético de todas as plantas de forma diferenciada dentro e entre as cultivares. A taxa fotossintética e condutância estomática diminuíram significativamente para todas as cultivares submetidas ao déficit hídrico. Nas plantas controle das cultivares tolerantes (SP832847 e CTC15) a taxa fotossintética foi maior do que a cultivar sensível (SP86-155). A cultivar CTC15 apresentou 0 teor relativo de água mostrou que a cultivar CTC15 apresentou o maior teor relativo de água durante o período de déficit hídrico. A eficiência fotossintética da cultivar SP83-2847 foi mais estável nos últimos dias do tratamento experimental, sugerindo que o decréscimo do teor relativo de água estimulou o ajustamento da capacidade fotossintética para tolerar as mudanças da disponibilidade hídrica. De modo geral, as cultivares tolerantes SP83-2847 e CTC15, apresentaram melhor desempenho fotossintético do que a cultivar 
sensível SP86-155. Os dados permitem sugerir que tais parâmetros fisiológicos podem ser usados na avaliação e distinção de genótipos de cana-de-açúcar tolerantes e sensíveis ao déficit hídrico.

Palavras-chave: Eficiência fotossintética, teor relativo de água, Saccharum, estresse hídrico, seca.

\section{INTRODUCTION}

Sugarcane (Saccharum spp.) is an important source for the production of sucrose and ethanol in many tropical regions. Brazil is the major world producer of sugarcane, followed by India, China and Thailand. In the 2009/2010 season, Brazilian enterprises processed around 612 million tons, and the 2010/2011 production is estimated at 664 million tons (Conab, 2010).

It is well known that the actual productivity of crops in many regions is only partly of the genetic potential of the plants (Taiz and Zeiger, 2006). Water deficit is one of the main factors reducing production for many crops (Bray et al., 2000), and sugarcane is especially affected by drought (Venkataramana et al., 1986). One alternative to mitigate water deficit in sugarcane is irrigation (InmanBamber, 2004); however, water is limited in some regions, and equipment costs make this strategy expensive (Boyer, 1996; Silva et al., 2007). The selection of genotypes that are tolerant to water deficits and their introduction in genetics breeding programs is one means of reducing these costs (Silva et al., 2007).

The stress caused by water deficit affects the entire plant, from root hairs to stomata. Morphological alterations including reductions in leaf area and root growth and stomatal closure when the plant is acclimating to drought are the main symptoms of water deficit (Davies et al., 2002; Gomez-DelCampo et al., 2002; Taiz and Zeiger, 2006; Lopez et al., 2008). Physiological responses can vary according to plant genotype, but in general, modifications related to water deficit include lower water potential in the soil and in the leaves (Steudle, 2000; Liberato et al., 2006), increases in osmoprotectors such as proline and sugars (Molinari et al., 2007; McCormick et al.; 2008), reduction in photosynthetic efficiency photosystem II (Angelopoulos et al., 1996; Silva et al., 2007), reduction in the relative water content in leaves (Silva et al., 2007; Wahid and Close, 2007; Lobato et al., 2008), and decrease in stomata conductance and the photosynthetic rate (Brestic et al., 1995; Du et al., 1996; Davies et al., 2002; Azevedo Neto et al., 2004; Smit and Singels, 2006).
In plants, the hydric balance is controlled by foliar transpiration and water capitation from the soil, which in adverse conditions such as water deficit, reduces the relative water content and photosynthetic activity (Lawlor and Cornic, 2002; Azevedo Neto et al., 2004; Smit and Singels, 2006). Quantum efficiency photosystem II and stomatal conductance are also rapidly reduced during water deficit (Miyashita et al., 2005).

Different methods can be used to distinguish water deficits between tolerant and sensible genotypes. Our research group has carried out molecular studies to investigate gene expression in sugarcane plants that are tolerant or sensitive to water deficit (Rodrigues et al., 2009). Thus, the objective of this study was to investigate the water deficit tolerance and sensibility process during the vegetative stage in sugarcane cultivars submitted to water deficit conditions.

\section{MATERIALS AND METHODS}

Experiment installation: Sugarcane plants were obtained from the "Centro de Tecnologia Canavieira" (CTC) at Piracicaba and the "Usina Santa Adélia" at Jaboticabal, both in the state of São Paulo. The evaluations were performed on the water deficit tolerant SP83-2847 and CTC15 cultivars and the SP86-155 water deficit sensitive cultivar. These cultivars were evaluated in field experiments and classified according to their productivity during long drought periods (Copersucar, 1999; CTC, 2007).

The experiment was performed in a greenhouse with temperature of $26 \pm 2^{\circ} \mathrm{C}$ and relative humidity of $60 \%$. The plants were irrigated by automatic sprinklers, four times a day (10h, $12 \mathrm{~h}, 15 \mathrm{~h}$ and $17 \mathrm{~h}$ ) for all cultivars. Plants were cultivated individually in $4 \mathrm{~L}$ pots, using oxysoil substrate.

For each cultivar, 72 plants were arranged in randomized blocksinthegreenhouse. The experimental procedureconsisted of 12 data collections (under water deficit conditions), using three replicates for control (irrigated) and three for treated (water deficit) plants. The water deficit treatment consisted of no irrigation, and the plants were analyzed on days 1,2 , $4,5,7,8,9,10,11,12,13$, and 14 after the beginning of 
water deficit. The control plants were irrigated daily during the experiment.

Physiological parameters analysis: All analyses were performed at the Ecophysiology Laboratory at Embrapa Soybean, Londrina, Paraná, Brazil, from March through May 2008. The third totally expanded leaf (McCormick et al., 2006) at each collection date (days 1, 2, 4, 5, 7, 8, 9, 10, 11, 13, and 14 of water deficit) was used to evaluated as follows: difference between leaf temperature and air temperature $\left({ }^{\circ} \mathrm{C}\right)$, transpiration rate $(E)$, photosynthetic rate $(A)$ and stomatal conductance $\left(g_{s}\right)$. All variables were analyzed in the Portable Photosynthesis System (LICor, model LI-6400, "IRGA") with photosynthetically active radiation $1000 \mu \mathrm{mol} \mathrm{m} \mathrm{m}^{-2} \mathrm{~s}^{-1}$. In these analyses, all values were taken considering a coefficient of variation less than $1 \%$.

Quantum efficiency photosystem II (PSII) and relative water content (RWC) were determined in all experimental treatments. PSIl was estimated using a Plant Efficiency Analyser portable system (PEA, Hansatech Instruments, Norfolk, UK). The RWC was measured based on Matin et al. (1989), with some modifications. Three leaf fragments were collected from the second totally developed leaf (McCormick et al., 2006) and immediately placed in a covered glass container to measure fresh sample weight. The turgid weight was obtained with rehydrated tissue by using deionized water (Milli-Q, Millipore) for $48 \mathrm{~h}$, at room temperature in the absence of light. After rehydration, the turgid weight was measured, and the samples were then placed in $80{ }^{\circ} \mathrm{C}$ for $48 \mathrm{~h}$ to obtain the dry weight. The RWC was calculated according to Matin et al. (1989), using the formula: (fresh weight - dry weight)/ (turgid weight - dry weight) *100. During the experiment, we also evaluated the capacity of cultivars to recover physiological parameters after being kept under water deficit and rehydrated on days 8 and 10 .

Statistical analyses: The experiment was performed in a randomized block with factorial arrangement, with three blocks, and three replicates per treatment in each block, as follows: three cultivars, two irrigation levels (irrigated and water deficit), and sampling time under water deficit, totaling 216 plants. Stomatal conductance data were converted to square root $(x+1)$ for analyses. After the ANOVA, the means were compared by Tukey test multiple comparison at the $5 \%$ probability level. All analyses were performed by means of the SAS - Statistical Analysis System (SAS Institute, 1996) statistical package.

\section{RESULTS}

Relative water content and foliar temperature: Tables 1 and 2 show the ANOVA values between the different treatments, which indicated highly significant differences. The results showed a significant difference in relative water content (RWC) in the stressed plants compared to the irrigated plants (Figure 1). According to the Tukey test $(P<0.05)$, the RWC showed significant differences between collecting times throughout the water deficit experiment, especially from day 7 on, for all the cultivars. Also at day 7, cv CTC15 showed a reduction of $10.52 \%$ in RWC in the water deficit plants. Reductions of $19.55 \%$ and 23.12\% were observed in SP83-2847 and SP86-155 RWC, respectively, in the same day. The tolerant and sensitive cultivars were rehydrated at days 8 and 10 during water deficit and at the first rehydration (day 8) the plants showed alterations in the leaf water status, where cultivars under water deficit showed RWCs similar to the control plants. However, in the second rehydration period on day 10 , the responses of the plants were not observed. A notable increase in RWC was detected in the stressed plants that were rehydrated on day 8 . These plants behaved differently on day 10 , suggesting that a critical point for the recuperation capacity of these plants is at a maximum of approximately 8 days (Figure 1).

During water deficit conditions, the RWC on day 7 in the tolerant cv CTC15 was reduced to $88.29 \%$, to $78.56 \%$ in the tolerant SP83-2847 and to $76.37 \%$ in the sensitive SP86-155. Comparing the RWC among the cultivars under water deficit (Figure 1), a significant variation was observed between the cultivars on days 7, 10 and 13; cv CTC15 showed the highest RWC in most evaluations. In the control plants, significant differences among cultivars were not observed, and the RWC remained between 95 and $100 \%$ (data not shown).

Table 1. Analysis of variance resume (degrees of freedom (DF) and $F$ value) for quantum efficiency photosystem II (PSII) and relative water content (RWC) estimated on three sugarcane cultivars under water deficit conditions.

\begin{tabular}{|c|c|c|c|}
\hline \multirow{2}{*}{ Variation } & \multirow{2}{*}{ DF } & \multicolumn{2}{|c|}{ F value } \\
\hline & & PSII & RWC \\
\hline Irrigation level (IL) & 1 & $172.75^{\star \star \star}$ & $775.31^{\text {*** }}$ \\
\hline Cultivar (CV) & 2 & $8.92^{\star \star}$ & $3.46^{*}$ \\
\hline Days (DS) & 11 & $12.46^{\star \star \star}$ & $51.98^{* * *}$ \\
\hline $\mathrm{IL} \times \mathrm{CV}$ & 2 & $4.80^{* *}$ & $5.96^{\star \star}$ \\
\hline $\mathrm{IL} \times \mathrm{DS}$ & 11 & $15.79 * * \star$ & $61.45^{\star \star *}$ \\
\hline $\mathrm{CV} \times \mathrm{DS}$ & 22 & $3.91^{* * *}$ & $9.59 * \star \star$ \\
\hline $\mathrm{IL} \times \mathrm{CV} \times \mathrm{DS}$ & 22 & $3.96^{\star * *}$ & $9.41^{* * *}$ \\
\hline Residual & 142 & - & - \\
\hline
\end{tabular}


Table 2. Analysis of variance resume (degrees of freedom (DF) and $F$ value) for temperature $\left({ }^{\circ} \mathrm{C}\right)$, transpiration rate $(E)$, photosynthetic rate $(A)$ and stomatal conductance $\left(g_{s}\right)$ of three sugarcane cultivars under water deficit conditions.

\begin{tabular}{|c|c|c|c|c|c|}
\hline \multirow{2}{*}{ Variation } & \multirow{2}{*}{ DF } & \multicolumn{4}{|c|}{ F value } \\
\hline & & ${ }^{\circ} \mathrm{C}$ & $E$ & $A$ & $g_{s}$ \\
\hline Irrigation levels (IL) & 1 & $185.66^{\star \star \star}$ & $289.37^{\star \star \star}$ & $306.04^{\star \star *}$ & $161.01^{\star \star \star}$ \\
\hline Cultivar (CV) & 2 & $7.89 * *$ & $29.96 * \star \star$ & $12.63^{\star \star \star}$ & $22.45^{\star \star \star}$ \\
\hline Days (DS) & 10 & $67.40^{\star \star \star}$ & $107.18^{* \star *}$ & $28.17^{\star \star \star}$ & $45.39 * \star *$ \\
\hline $\mathrm{IL} \times \mathrm{CV}$ & 2 & $7.53^{\star \star}$ & $10.77^{\star \star \star}$ & $9.24^{\star *}$ & $5.19^{\star \star}$ \\
\hline $\mathrm{IL} \times \mathrm{DS}$ & 10 & $8.02^{\star \star \star}$ & $10.11^{\star \star \star}$ & $12.20 * \star *$ & $10.22^{* * *}$ \\
\hline $\mathrm{CV} \times \mathrm{DS}$ & 20 & $2.45^{\star \star}$ & $3.43^{\star \star *}$ & $2.70^{\star *}$ & $2.13^{\star \star}$ \\
\hline $\mathrm{IL} \times \mathrm{CV} \times \mathrm{DS}$ & 20 & $3.00^{\star *}$ & $4.44^{* * *}$ & $2.96^{\star \star}$ & $4.07^{\star \star \star}$ \\
\hline Residual & 130 & & & - & - \\
\hline
\end{tabular}

${ }^{* * \mathrm{P}}<0,01,{ }^{* * * \mathrm{P}}<0,001$

SP83-2847
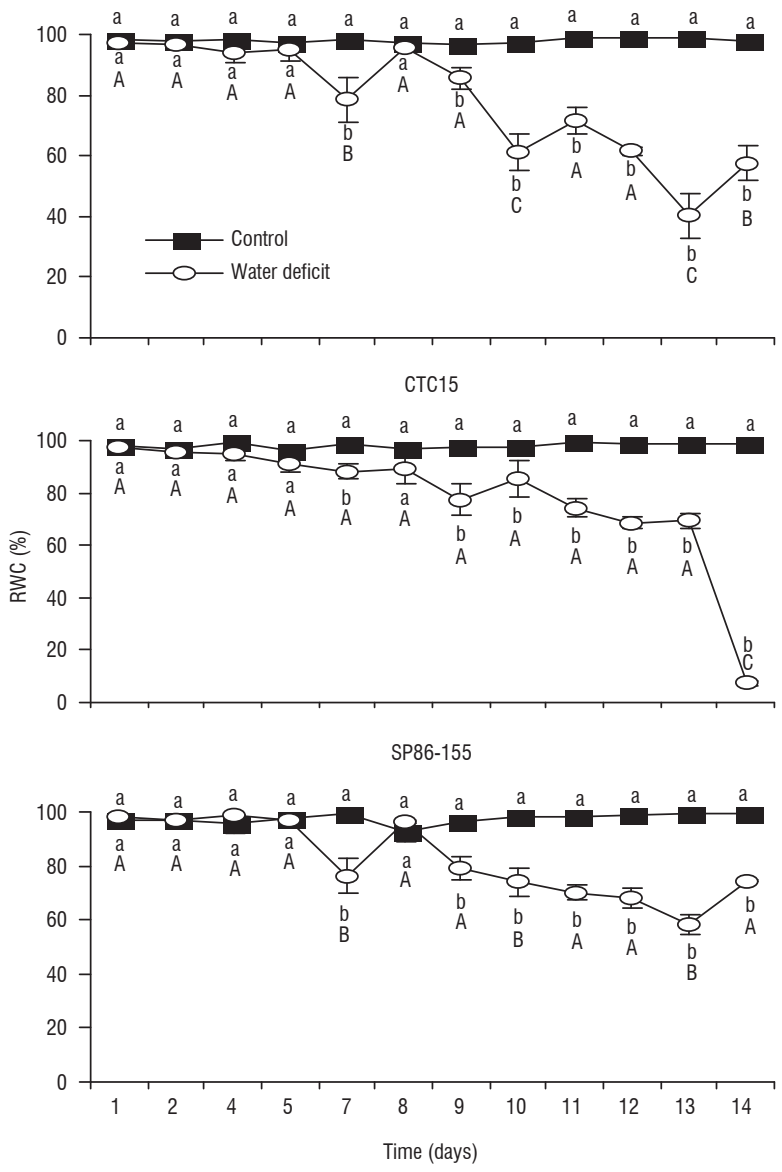

Figure 1. Relative water content (RWC) in sugarcane cultivars SP83-2847, CTC15 and SP86-155 (lower case letters) under water deficit. Comparison RWC among cultivars under water deficit (capital letters). Means followed by the same letter on day are not significantly different by the Tukey's test at $5 \%$ probability level.
The results obtained on seventh day showed a significant increase in foliar temperature in the tolerant SP83-2847 and sensitive SP86-155 cultivars (Figure 2). In cv CTC15, the increase in leaf temperature occurred earlier, on day 4 . On rehydration, the stressed plants on days 8 and 10 showed a lower temperature. During the same period, the transpiration rate differed statistically from day 7 for tolerant SP83-2847 and sensitive SP83-2847 cultivars and on day 3 for Cv CTC15 (Figure 3).
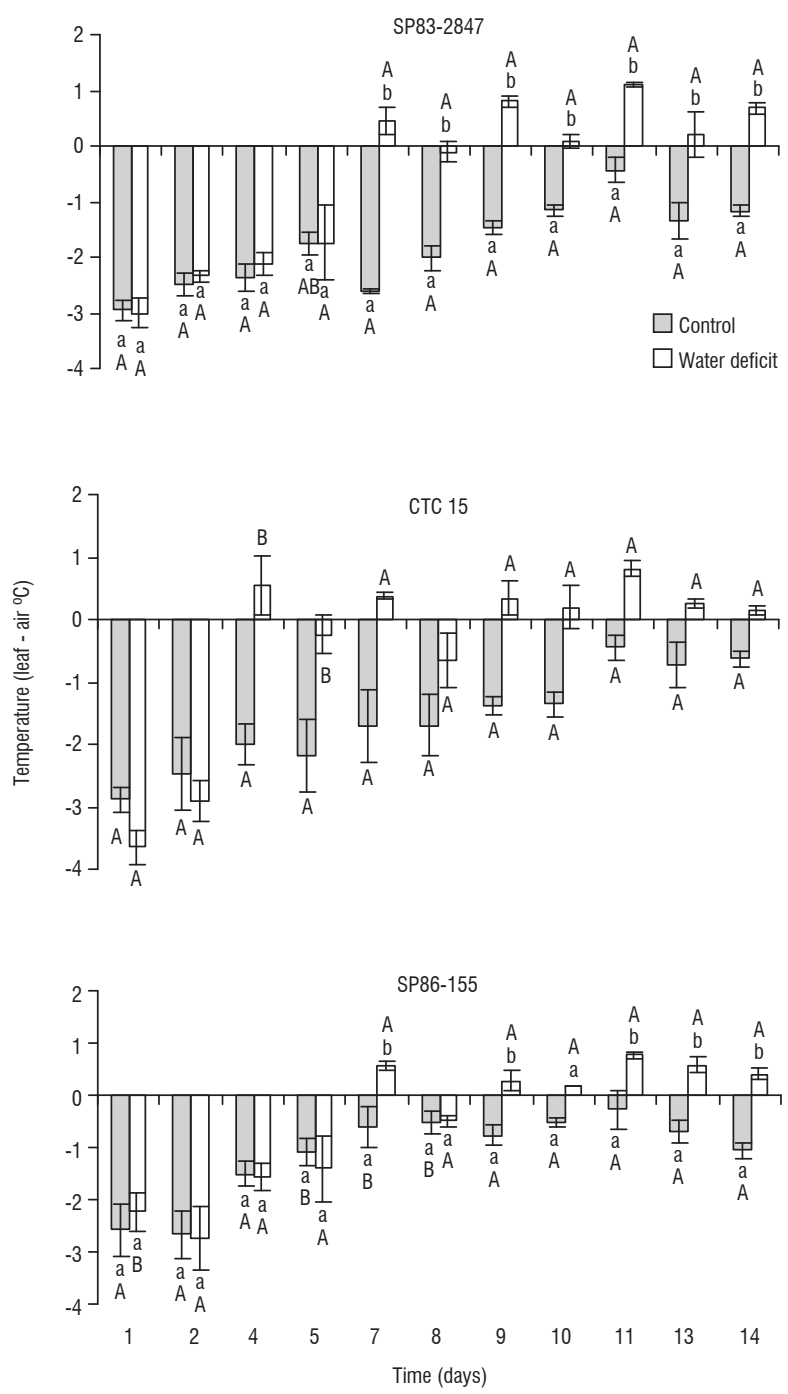

Figure 2. Difference between foliar and air temperature. Temperature variation within sugarcane cultivars SP83-2847, CTC15 and SP86-155 (lower case letters) under water deficit. Temperature comparison between cultivars under control conditions (capital letters in control plants bar) and under water deficit conditions (capital letters in water deficit plants bar). Positive values indicate foliar temperature higher than the room temperature. Means followed by the same letter on day are not significantly different by Tukey's test at $5 \%$ probability level. 


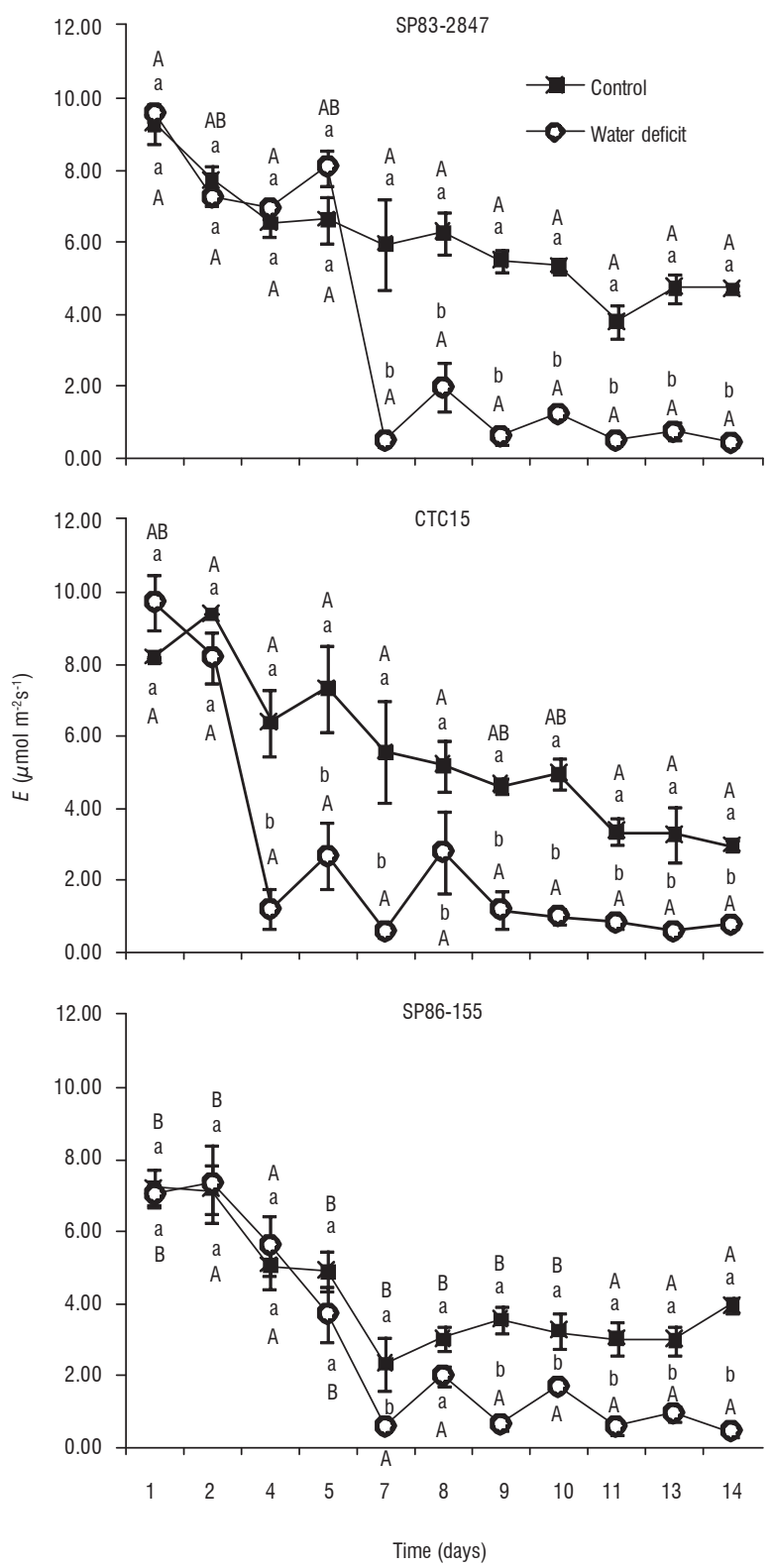

Figure 3. Transpiration rate $(E)$ within sugarcane cultivars SP83-2847, CTC15 and SP86-155 (lower case letters). Comparison between cultivars control conditions (capital letters in control plants line) and among cultivars under water deficit conditions (capital letters in water deficit plants line). Means followed by the same letter on day are not significantly different by Tukey's test at $5 \%$ probability level.

Quantum efficiency photosystem II: Tolerant cultivars SP83-2847 and CTC15 showed a decline in PSIl from day 7 of water deficit, especially in cv SP83-2847 (Figure 4). With the rehydration of plants on days 8 and 10, the PSII of the stressed plants showed a recovery, as observed on days 8 , 9, 10, and 11. In sensitive cv SP86-155, a less accentuated decrease in PSII was observed on day 12. At both rehydration periods, days 8 and 10, the plants submitted to water deficit showed a PSIl value very close to that of the control plants.

When the cultivars were compared under water deficit conditions (Figure 4), a decrease in photosynthesis efficiency (PSII) was observed at days 13 and 14 for Cv CTC15, and at days $12 \cdot 13$ and 14 for SP86-155. Cultivar SP83-2847 at day 12 showed lower efficiency. In sensitive cv SP86-155, the PSIl values decreased to approximately 0.40 at day 12 , dropping to 0.36 at day 13 of water deficit; whereas the tolerant plants showed values of approximately 0.60 . In general, tolerant cultivars SP83-2847 and CTC15 submitted to water deficit showed better PSII than cv SP86-155 (Figure 4). Comparing cultivars, the PSIl of control plants was not different (data not shown).
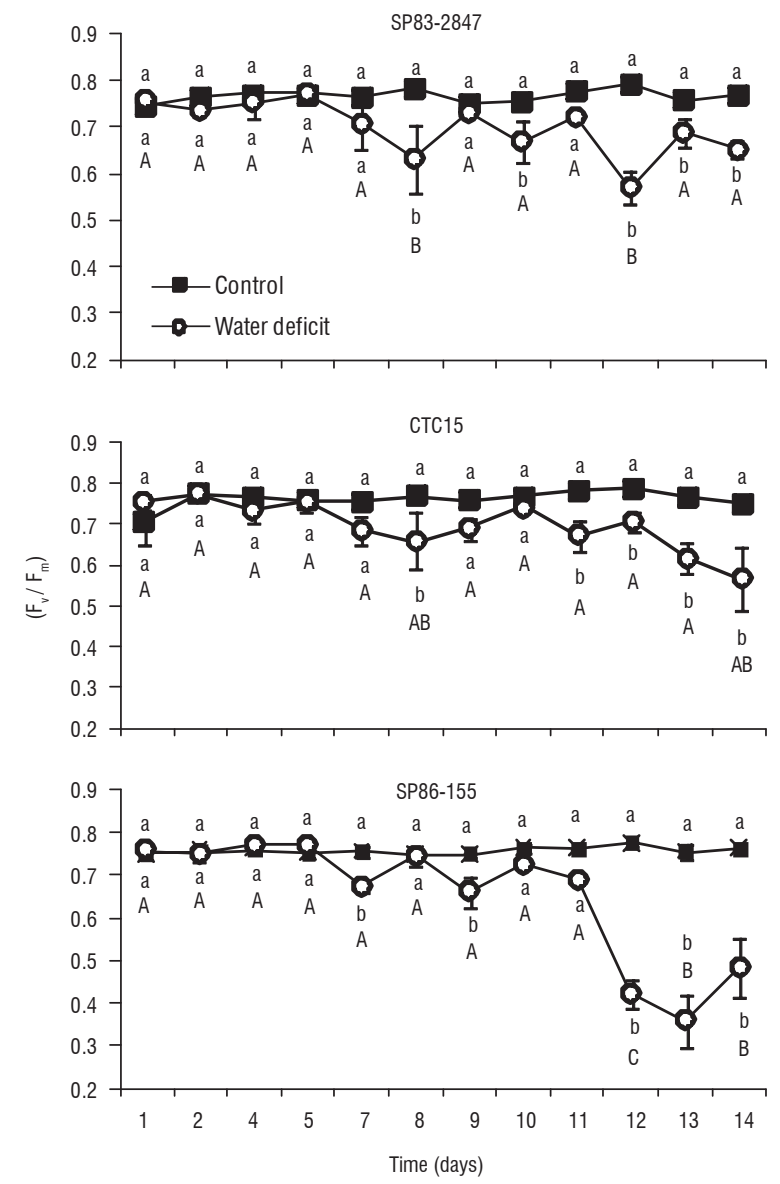

Figure 4. Quantum efficiency PSII $\left(F_{v} / F_{m}\right)$ within sugarcane cultivars SP832847, CTC15 and SP86-155 (lower case letters). Comparison among cultivars under water deficit (capital letters). Means followed by the same letter on day are not significantly different by Tukey's test at $5 \%$ probability level.

Photosynthetic rate: The photosynthetic rate was significantly different between irrigated and water deficit plants for cultivars SP83-2847 and SP86-155 from day 7, and for 
cv CTC15 from day 4 (Figure 5). After rehydration at day 8, the plants exhibited a small increase in photosynthetic rate for cultivars CTC15 and SP86-155, as observed from the second rehydration, at day 10 , for all cultivars. In general, all cultivars were affected by the imposition of water deficit conditions; as shown in Figure 5, cultivars SP83-2847 $\left(1.7 \mu \mathrm{mol} \mathrm{m}^{-2} \mathrm{~s}^{-1}\right)$ and SP86-155 $\left(2.12 \mu \mathrm{mol} \mathrm{m}^{-2} \mathrm{~s}^{-1}\right)$ exhibited a photosynthetic rate higher than cv CTC15 $\left(0.38 \mu \mathrm{mol} \mathrm{m} \mathrm{m}^{-2} \mathrm{~s}^{-1}\right)$ at day 14 . A significant difference among cultivars was observed at days 4 and 7 in plants submitted to water deficit (Figure 5). Photosynthetic rate also varied in the control plants. Tolerant cultivars SP83-2847 and CTC15 exhibit better performance compared to sensitive cultivar SP86-155 (Figure 5).
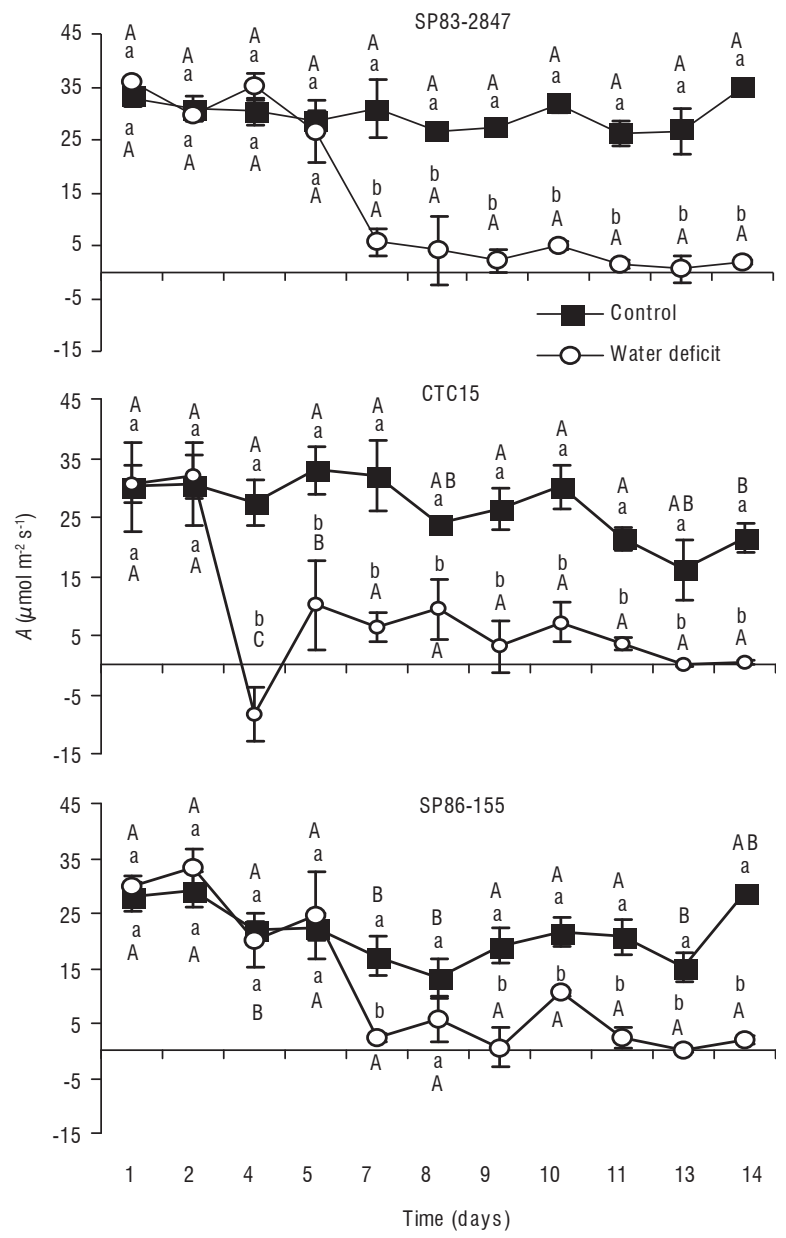

Figure 5. Photosynthetic rate $(A)$ within sugarcane cultivars SP83-2847, CTC15 and SP86-155 (lower case letters). Comparison among cultivars control conditions (capital letters in control plants line) and among cultivars under water deficit (capital letters in water deficit plants line). Means followed by the same letter on day are not significantly different by Tukey's test at $5 \%$ probability level.

Stomatal conductance and transpiration rate: Stomatal conductance values during the entire period of water deficit treatment are presented in Figure 6. The water deficit of $\mathrm{cv}$
SP83-2847 plants was higher $\left(1.16 \mathrm{~mol} \mathrm{~m}^{-2} \mathrm{~s}^{-1}\right)$ at day 5 compared to control plants $\left(1.11 \mathrm{~mol} \mathrm{~m}^{-2} \mathrm{~s}^{-1}\right)$; however, on day 7 this value decreased and remained at $1.009 \mathrm{~mol} \mathrm{~m}^{-2} \mathrm{~s}^{-1}$ during the remaining experimental period. From day 4 , stomatal conductance in $\mathrm{cv}$ CTC15 plants submitted to water deficit differed significantly from control plants, and these differences continued during the entire experimental treatment. However, $\mathrm{cv}$ SP86-155 plants submitted to water deficit differed statistically from control plants at days $9,11,13$, and 14 .

Comparing the stomatal conductance of plants submitted to water deficit, the tolerant cultivars (SP83-2847 and CTC15) and the sensitive cultivar (SP86-155) showed significant differences $(P<0.05)$ at days 1,4 and 5 (Figure 6$)$. In control plants, cv SP83-2847 differed from SP86-155 at days 7 and 8 , and in general, throughout the experimental treatment, cv SP83-2847 performed best for stomatal conductance, followed by cv CTC15.

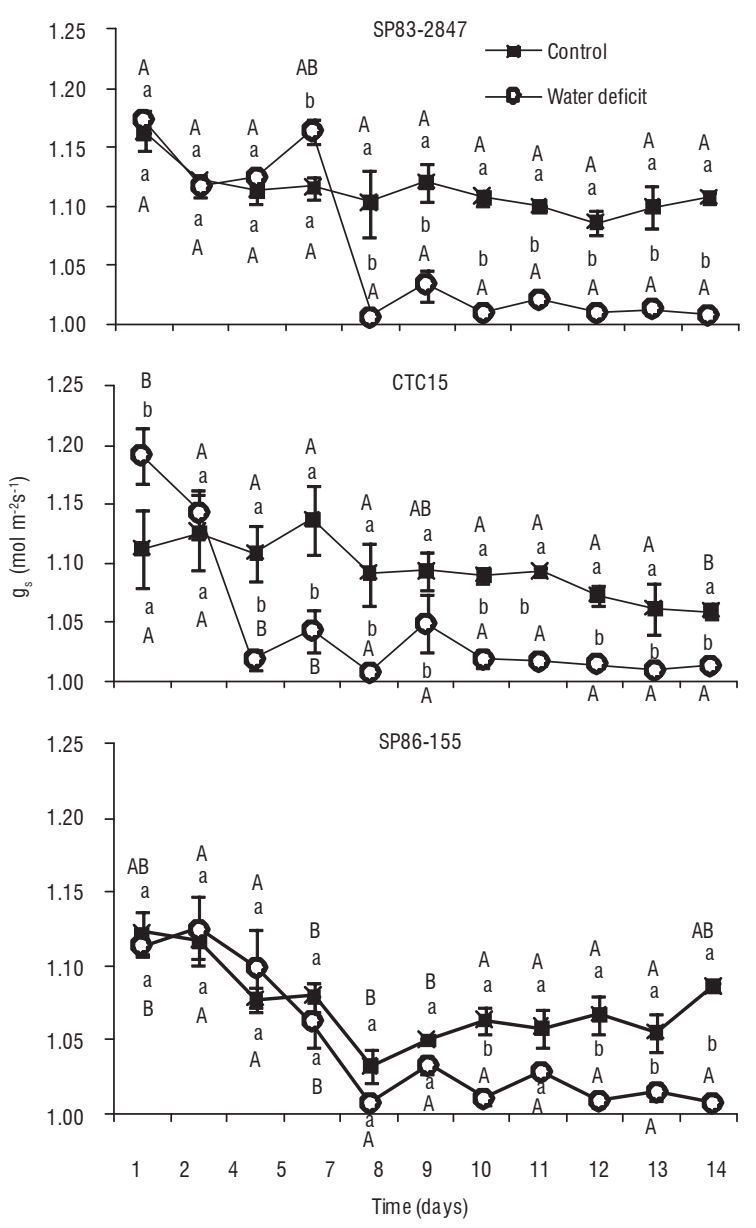

Figure 6. Stomatal conductance $\left(\mathrm{g}_{\mathrm{s}}\right)$ within sugarcane cultivars SP83-2847, CTC15 and SP86-155 (lower case letters). Comparison among cultivars control conditions (capital letters in control plants line) and among cultivars under water deficit (capital letters in water deficit plants line). Means followed 
by the same letter on day are not significantly different by Tukey's test at $5 \%$ probability level.

\section{DISCUSSION}

This study demonstrated variations in RWC, temperature, PSII, transpiration rate, photosynthetic rate and stomatal conductance among three sugarcane cultivars submitted to water deficit treatment. In general, tolerant cultivars SP83-2847 and CTC15 exhibited better performance under water deficit condition compared to sensitive cv SP86-155, considering physiological parameters such as RWC and PSII. Colom and Vazzana (2003) evaluated the recovery capacity of two tolerant and sensitive cultivars of Eragrostis curvula submitted to water deficit, and also observed a better RWC recovery in the drought tolerant plants.

The percentages of RWC reduction in sugarcane plants submitted to water deficit, in the present study, were close to $60 \%$ at day 10 for cv SP83-2847 (61.04\%), cv CTC15 (69.33\%) and also cv SP86-155 (58.52\%). In Zea mays plants under water deficit treatment, three days were sufficient to reduce the RWC to $65 \%$ (Schlemmer et al., 2005). However, in other plant families, RWC reduction can occur rapidly. In Lycopersicon esculentum, a 50\% reduction of RWC was observed 20 hours after the beginning of water deficit treatment. However, after 40 hours the RWC dropped to $40 \%$, suggesting that in these plants the stress effect was more accentuated in the first hours of water deficit (Havaux, 1992).

Under high temperature conditions, Wahid and Close (2007) observed that Saccharum officinarum plants showed a reduction in RWC. However, 72 hours after the beginning of water deficit, the stressed plants showed RWC values similar to the control plants, suggesting that plants utilize part of their water content to minimize damage due to high temperature. The values obtained in present study suggest that cv CTC15 was able to detect a minimum reduction in the amount of water available for absorption, favoring water deficit tolerance, because this plant could preserve its water content through stomatal closure (Figure 6).

Because water is the principal electron donor for PSII, through the oxidation process, a decrease in RWC can decrease the electrochemical potential of ATP synthase and photosystem I, compromising ATP formation and NADPH respectively and thus negatively affecting the photosynthetic apparatus (Taiz and Zeiger, 2006; Lawlor and Cornic, 2002). This information agrees with data obtained in the present research, i.e., when RWC decreased in plants submitted to water deficit, a reduction in PSIl was also observed. At day 8 , when the plants were rehydrated, the elevated RWC likely led to an increase in PSII. Cha-Um and Kirdmanee (2008) observed a significant decrease in PSII in sugarcane submitted to drought. These authors demonstrated reductions in PSII, transpiration rate, and stomatal conductance which are in agreement with present our observations.

A water deficit decreases foliar transpiration due to stomatal closure, thus increasing foliar temperature. Exposure of Tritium aestivum to water deficit, associated with heat stress, also altered the PSII, and lower PSII was observed in irrigated plants (control) at 35,40 and $45^{\circ} \mathrm{C}$ (Lu and Zhang 1999). According to authors, an antagonist effect occurs between water deficit and high temperature stress, the former being responsible for increasing PSII resistance. In the present study, PSII decreased significantly during water deficit in all cultivars. This suggests that when plants are submitted only to water deficit, no increase in PSII resistance occurs. Therefore, when RWC began to decrease from day 7, PSII also decreased on day 8 , in plants under water deficit. Consequently, the observed efficiency of PSII in sugarcane under water deficit may be more related to RWC than to the other parameters evaluated.

According to Taiz and Zeiger (2006), one of the main PSII inhibitor agents seems to be the excess of photons leading to photoinhibition, which causes increases in phototoxic products such as superoxide $\left(\mathrm{O}_{2}^{-}\right)$, hydrogen peroxide $\left(\mathrm{H}_{2} \mathrm{O}_{2}\right)$, and the hydroxide radical $\left(\mathrm{OH}^{-}\right)$which oxidates the PSII D1 protein. The damage caused by water deficit to sugarcane cultivars may have been less harmful to the PSIl than to other physiological parameters such as the photosynthetic rate and stomatal conductance, considering the rapid decreases in plants under water deficit. In Eragrostis curvula, an African grass adapted to semi-arid regions, differences were observed in PSII in sensitive (0.2) and tolerant (0.5) cultivars, after 15 days no irrigation. However, when rehydrated for five days, the stressed plants reached similar PSII levels to those observed in control plants, indicating the recovery capacity of plant PSII (Colom and Vazzana, 2003).

The time interval between rehydration and the plant physiological response varies according to plant species, the 
parameters evaluated, and the water deficit imposed (Liberato et al., 2006; Souza et al., 2004). In Olea europaea, five days of rehydration were sufficient to reestablish the photosynthetic rate, water potential of leaves, and PSII, reaching levels similar to control plants (Angelopoulos et al., 1996). In sugarcane, only RWC and PSII increased on day 8 due to rehydration. Silva et al. (2007) evaluated the PSII in other water deficit tolerant and sensitive sugarcane genotypes, and observed significant decreases in the PSII among them. These data are in accordance with the observations in this work, where on days 12 and 14, tolerant cultivars SP83-2847 and CTC15 differed from sensitive cv SP86-155.

According to Chartzoulakis et al. (2002), a rapid decrease in photosynthetic rate is related to stomatal closure. In the present study, the photosynthetic rate declined rapidly in all cultivars, mainly in cv CTC 15, after 4 days under water deficit. In contrast, in Oryza sativa, photosynthetic efficiency decreased gradually (Yang et al., 2002).

The photosynthetic rate of Olea europaea reached zero under water deficit (Angelopoulos et al., 1996); however, when rehydrated for five days, the plants recovered their former photosynthetic rate. In sugarcane cv CTC 15 (9.39 $\left.\mu \mathrm{mol} \mathrm{m} \mathrm{m}^{-2} \mathrm{~s}^{-1}\right)$ and cv SP86-155 (10.47 $\left.\mu \mathrm{mol} \mathrm{m}^{-2} \mathrm{~s}^{-1}\right)$ plants, the photosynthetic rate recovered at days 8 and 10 after water stress, respectively. Similar results were reported for Minquartia guianensis, which also did not lose photosynthesis and PSII recovery capacity after 35 days under water stress conditions (Liberato et al., 2006).

Stomatal conductance seems to be directly related to a reduction in RWC in plants under water deficit, as foliar transpiration is controlled by stomatal opening and closure (Taiz and Zeiger 2006). In this study, when RWC declined between $10 \%$ and $20 \%$, all the sugarcane cultivars showed a reduction in stomatal conductance. The decrease of stomatal conductance in plants under water deficit is similar to the behavior of saline stressed plants, because both conditions compromise water absorption (López-Climent et al., 2008).

Decreases in the photosynthetic rate and stomatal conductance, in general, are related. Considering that $\mathrm{CO}_{2}$ flux control in leaves is mediated by stomatal opening, photosynthesis is also mediated by regular water availability (Taiz and Zeiger, 2006). This explains the significant decrease in transpiration rate that we observed in all the cultivars during the entire water deficit experimental period, together with the increase in foliar temperature in plants under stress, likely due to low stomatal conductance. In Phaseolus vulgaris, stomatal conductance and photosynthetic rate also declined rapidly after two days without irrigation (Miyashita et al., 2005). The decline in stomatal conductance seems to be a common process in many plant species during water deficit, and its effects are observed in the lower transpiration rate as well as an increase in foliar temperature (Liberato et al., 2006; Azevedo Neto et al., 2004).

According to the physiological parameters RWC and PSII, tolerant cultivars SP83-2847 and CTC15 performed better under water deficit conditions compared to the sensitive cv SP86-155. Cultivars SP83-2847 and CTC15, irrigated daily, showed a higher photosynthetic rate, stomatal conductance, and transpiration rate. Contrarily, sensitive plants SP86-155 did not show efficient physiological performance, even under continuous irrigation. After the rehydration period, some physiological parameters such as photosynthetic rate and stomatal conductance did not recover in any of the tolerant or sensitive plants. Additional studies are needed to associate the data on plant physiological behavior obtained here with gene expression, or to the action of sugar and osmoprotectors on the plant defense metabolism, relating these to the pathways involved in the response of sugarcane to drought.

Acknowledgments: The first author thank to CAPES for the scholarship concession.

\section{REFERENCES}

Angelopoulos K, Dichio B, Xiloyannis C. 1996. Inhibition of photosynthesis in olive trees (Olea europaea L.) during water stress and rewatering. J. Exp. Bot. 47: 1093-1100

Azevedo-Neto AD, Prisco JT, Enéas-Filho J, Lacerda CF, Silva JV, Costa PHA, Gomes-Filho E. 2004. Effects of salt stress on plant growth, stomatal response and solute accumulation of different maize genotypes. Braz. J. Plant Physiol. 16: 31-38

Brestic M, Cornic G, Fryer MJ, Baker NR. 1995. Does photorespiration protect the photosynthetic apparatus in French bean leaves from photoinhibition during drought stress? Planta 196: 450-457

Chartzoulakis K, Patakas A, Kofidis G, Bosabalidis A, Nastou A. 2002. Water stress affects leaf anatomy, gas exchange, water relations and growth of two avocado cultivars. Sci. Hortic. 95:39-50

Cha-Um S, Kirdmanee C. 2008. Effect of osmotic stress on proline accumulation, photosynthetic abilities and growth of sugarcane plantlets (Saccharum officinarum L.). Pak. J. Bot. 40:2541-2552

Colom MR, Vazzana C. 2003. Photosynthesis and PSIl functionality of drought-resistant and droght-sensitive weeping lovegrass plants. Environ. Exp. Bot. 49:135-144 
Conab 2010. Companhia Nacional de Abastecimento. Available at: < http:// www.conab.gov.br/conabweb/download/safra/1_levantamento2010 abr2010.pdf> Accessed 10 May 2010.

Copersucar 1999. Cooperativa de produtores de cana-de-açúcar, açúcar e álcool do Estado de São Paulo. Piracicaba: Copersucar. 32p. (technical bulletin).

CTC 2007. Centro de Tecnologia Canavieira. Piracicaba: CTC. 20p. (technical bulletin).

Davies WJ, Wilkinson S, Loveys B. 2002. Stomatal control by chemical signaling and the exploitation of this mechanism to increase water use efficiency in agriculture. New Phytol. 153:449-460.

Du YC, Kawamitsu Y, Nose A, Hiyane S, Murayama S, Wasano K, Uchida Y. 1996. Effects of water stress on carbon exchange rate and activities of photosynthetic enzymes in leaves of sugarcane (Saccharum sp.). Aust. J. Plant Physiol. 23:719-726.

Du YC, Nose A, Wasano K. 1999. Thermal characteristics of C4 photosynthetic enzymes from leaves of three sugarcane species differing in cold sensitivity. Plant Cell Physiol. 40:298-304.

Gomez-Del-Campo M, Ruiz C, Lissarrague JR. 2002. Effect of water stress on leaf area development, photosynthesis, and productivity in Chardonnay and Airén grapevines. Am. J. Enol. Viticult. 53:138-143.

Gonçalves MC, Vega J, Oliveira JG, Gomes MMA. 2005. Sugarcane yellow leaf virus leads to alterations in photosynthetic efficiency and carbohydrate accumulation in sugarcane leaves. Fitopatol. Bras. 30:10-16.

Havaux M. 1992. Stress tolerance of photosystem II in vivo: antagonistic effects of water, heat, and photoinhibition stress. Plant Physiol. 100:424432.

Inman-Bamber NG. 2004. Sugarcane water stress criteria for irrigation and drying off. Field Crops. Res. 89:107-122.

Lawlor DW, Cornic G. 2002. Photosynthetic carbon assimilation and associated metabolism in relation to water deficits in higher plants. Plant Cell Environ. 25:275-294.

Liberato MAR, Goncalves JFC, Chevreuil LR, Nina Junior AR, Fernandes AV, Santos Junior UM. 2006. Leaf water potential, gas exchange and Chlorophyll a fluorescence in acariquara seedlings (Minquartia guianensis Aubl.) under water stress and recovery. Braz. J. Plant Physiol. 18:315-323.

Lobato AKS, Oliveira Neto CF, Costa RCL, Santos Filho BG, Cruz FJR, Laughinghouse HD. 2008. Biochemical and physiological behabior of Vigna unguiculata (L.) walp. under water stress during the vegetative phase. Asian J. Plant Sci. 7:44-49.

Lopez FB, Chauhan YS, Johansen C. 2008. Effects of Timing of Drought Stress on Leaf Area Development and Canopy Light Interception of Shortduration Pigeonpea. J. Agron. Crop Sci. 178:1-7.

López-Climent MF, Arbona V, Pérez-Clemente RM, Gómez-Cadenas A. 2008. Relationship between salt tolerance and photosynthetic machinery performance in citrus. Environ. Exp. Bot. 62:176-184.
Lu D, Zhang J. 1999. Effects of water stress on photosystem II photochemistry and its thermostability in wheat plants. J. Exp. Bot. 50:1199-1206.

Matin MA, Brown JH, Fergunson H. 1989. Leaf water potential, relative water content, and diffusive resistance as screening techniques for drought resistance in barley. Agron. J. 81:100-105.

Mccormick AJ, Cramer MD, Watt DA. 2006. Sink strength regulates photosynthesis in sugarcane. New Phytol. 171:759-770.

Mccormick AJ, Cramer MD, Watt DA. 2008. Culm sucrose accumulation promotes physiological decline of mature leaves in ripening sugarcane. Field Crops Res. 108: 250-258.

Miyashita K, Tanakamaru S, Maitani T, Kimura K. 2005. Recovery responses of photosynthesis, transpiration, and stomatal conductance in kidney bean following drought stress. Environ. Exp. Bot. 53: 205-214.

Molinari HBC, Marur CJ, Daros E, Campos MKF, Carvalho JFRP, Bespalhok Filho JC, Pereira LFP, Vieira LGE. 2007. Evaluation of the stress-inducible production of proline in transgenic sugarcane (Saccharum spp.): osmotic adjustment, chlorophyll fluorescence and oxidative stress. Physiol. Plant 130:218-229

Rodrigues FA, Laia ML, Zingaretti SM. 2009. Analysis of gene expression profiles under water stress in tolerant and sensitive sugarcane plant. Plant Sci. 176: 286-302

Schlemmer MR, Francis DD, Shanahan JF, Schepers JS. 2005. Remotely measuring chlorophyll content in corn leaves with differing nitrogen levels and relative water content. Agron. J. 97:106-112.

Silva MA, Jifon JL, Da Silva JAG, Sharma V. 2007. Use of physiological parameters as fast tools to screen for drought tolerance in sugarcane. Braz. J. Plant Physiol. 19:193-201.

Smit MA, Singels S. 2006. The response of sugarcane canopy development to water stress. Field Crops Res. 98:91-97.

Souza RP, Machado EC, Silva JAB, Lagôa AMMA, Silveira JAG. 2004. Photosynthetic gas exchange in cowpea (Vigna unguiculata) during water stress and recovery. Environ. Exp. Bot. 51:45-56.

Steudle E. 2000. Water uptake by roots: effects of water deficit. J. Exp. Bot. 51:1531-1542.

Taiz L, Zeiger E. 2006. Plant Physiology. $4^{\text {th }}$ ed. Sinauer Associates, Inc. Publishers, Massachusetts.

Venkataramana S, Guruja RPN, Naidu KM. 1986. The effects of water stress during the formative phase on stomatal resistance and leaf water potentia and its relationship with yield in ten sugarcane varieties. Field Crops Res. 13:345-353.

Wahid A, Close TJ. 2007. Expression of dehydrins under heat stress and their relationship with water relations of sugarcane leaves. Biol. Plantarum 51:104-109.

Yang J, Zhang J, Wang Z, Zhu Q, Liu L. 2002. Abscisic acid and cytokinins in the root exudates and leaves and their relationship to senescence and remobilization of carbon reserves in rice subjected to water stress during grain filling. Planta 215:645-652. 